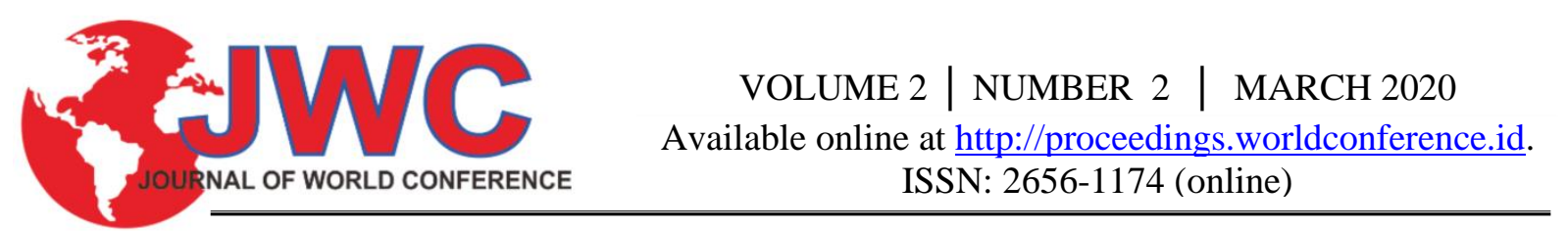

\title{
Risk Analysis Of Jakarta Pramuka Market Area Management To Improve Customer Satisfaction
}

\author{
Ali Sunandar and Muhammad Agfi Alfian \\ Civil Engineering, Mercu Buana University, J1. Raya Kranggan No.6, West Java, Indonesia \\ Ali.sunandar@gmail.com, muhammadagfi@gmail.com
}

\begin{abstract}
This research dilator behind how big the influence of risk factors that exist in the Jakarta scout market area to increase customer satisfaction. This study aims to determine the dominant factors causing management risks that exist in the Jakarta scout market area related to increased customer satisfaction. This study aims to determine the dominant factors causing the management risks that exist in the Scouting Market Area to obtain some of the most influential risks and develop strategies to be able to increase customer satisfaction in the Scouting Market Area. The study used a survey method in the form of asking questions to several respondents. This survey was conducted by distributing questionnaires and interviews with relevant parties that were used as a source of information. From the results of data processing with a statistical data processing application, several high risks have an impact on customer satisfaction and get a strategy to reduce these impacts.
\end{abstract}

Keywords: Risk Analysis, Market Management, Market Infrastructure, Customer Satisfaction, Scout Market.

\section{Introduction}

The existence of markets, especially traditional markets, is one of the most tangible indicators of community economic activity in an area. Market managers in accordance with their duties and functions have a strategic role in making markets a city economic infrastructure and providing business facilities that are feasible and comfortable for the community. The main market management is in terms of services, which include a collection of fees, permits, the arrangement of business premises for security and market order, as well as services using other traditional market facilities (Maesaroh, 2015).

One of the markets frequented by consumers in the city of Jakarta is the Pramuka Market. This market is a shopping place that is very well known by the people of Jakarta and surrounding areas. Some shops that sell complete medical devices and there is also a bird market located behind the scout market is a special attraction for customers. The existence of a scout market with a layout for traders is actually very helpful for customers to be able to get what they need, it's just that there are still some shortcomings associated with risks that can interfere with customer satisfaction when visiting. It can be seen the clutter that occurs in the scout market due to the meeting of traders and buyers, as well as the visitors who come with vehicles that cause the parking lot does not look conducive and seem messy.

Standardized management of traditional markets requires a correct understanding of market risk management in order to provide services that are both safe and comfortable in terms of traders, consumers and managers/government. Market management risks so far have only been seen in terms of tangible risks such as fires, garbage piling up and blocked channels. However, many intangible risks that exist in the market have not been able to be properly identified. Indeed, market management risks cannot be avoided but must be managed and controlled appropriately and sustainably, especially in the direction of SNI-standard markets so a mapping market risk is no longer an option but an absolute necessity that must exist.

The objectives of this study are:

1. To find out the dominant factors causing management risks that exist in the Pramuka Market Area.

2. To find out the risk management strategy in the Pramuka Market Area for customer satisfaction.

\section{Literature Review}

\subsection{Pasar Pramuka}

Pasar Pramuka is one of the markets in Jakarta which is famous as a center for medical equipment and is managed by PD Pasar Jaya. This market was established in 1975, consisting of four floors. Starting from the laboratory equipment, medical devices and drugs you can get. This market is located on Jalan Pramuka, East Jakarta. Pramuka Market is famous for the price being sold below the market price and has a complete product. The drug centers at the Boy pramuka market start at 08:00 until it closes at 19:00, the rush hour at noon. 


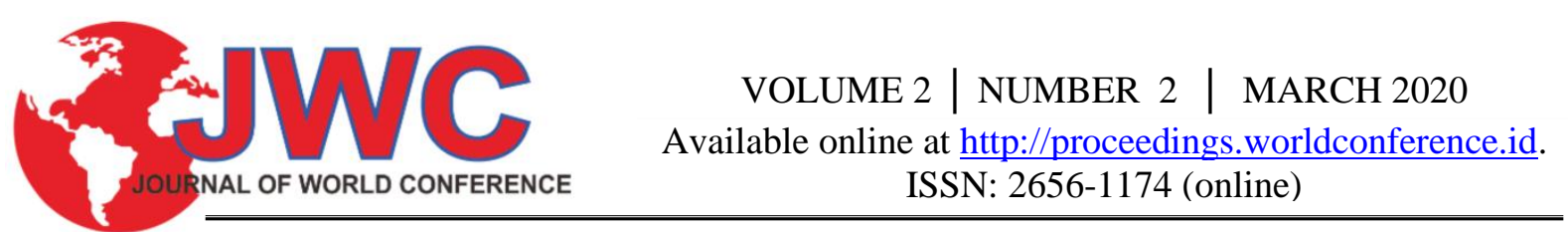

Bird markets also exist in the Boy Scout area. The pramuka bird market has existed since 1974, but at the time of the emergence of the bird virus in 2004, this bird market was suspended because there were so many people who were afraid of holding birds or even visiting the market. But now that drugs and vaccines have been found for birds to prevent contracting the bird flu virus, the scout market is becoming crowded again. In addition, in 2015 the scout bird market experienced a fire which resulted in several stalls being burned by fire. Because of this, the scout bird market has now built a new building that can be used to sell to traders whose stalls had caught fire.

\subsection{Risk management}

According to PMBOK-Sixth Edition (2018), Risk Management is the process of defining how to carry out risk management activities for a project. The main benefit of this process is ensuring that the degree, type, and visibility of risk management are proportionate to the risk and importance of the project for the organization and other stakeholders. This process is carried out once or at a predetermined point in the project. are needed.

Project requirements determine which components of the project management plan and project documents

\subsection{Risk Analysis}

Risk analysis is a technique for identifying and assessing factors that can jeopardize the success of a business, program, project, or individual to achieve goals. This technique also helps determine precautions to reduce the likelihood of that factor occurring and identifies actions that succeed in addressing the constraints that develop PMBOK-Sixth Edition (2018).

Risk analysis is part of risk management, which consists of the following steps:

1. Identification of possible external, internal and negative conditions, events, or situations

2. Determination of the causal relationship between the chance of the event, its scale, and the likely impact

3. Evaluate various impacts under different assumptions and probabilities

4. Application of qualitative and quantitative techniques to reduce uncertainty from impacts and costs, liabilities, or losses

\subsection{Risk Response}

Risk management is the process of developing options and determining actions to increase opportunities and reduce threats to project objectives. The risk response obtained is in the form of preventive action as a preventive measure to reduce the impact of the risk, and corrective action as a corrective action so that things that do not cause a negative impact have been repeated so the results will be returned to the expert for validation, what if appropriate, the results are distributed back to the new group of experts to get a response to the risks that have been identified. The experts selected for this activity are previous expert groups and experts who have a higher level than previous expert groups, namely those who have competence as policymakers (PMBOK, 2018).

\section{Research Method}

Research methods are scientific ways to obtain data with specific purposes and use. The scientific way means that research activities are based on scientific characteristics, namely rational, empirical and systematic. Rational means that research is carried out in ways that make sense so that it is affordable by human reasoning.

The method used in this study is data collection through interviews with respondents, questionnaires given to respondents as primary data. And data collection sourced from previous literature and journal studies as secondary data.

\subsection{Place and time of research}

This final project research was conducted in the scout market area. The following are the data related to the Pramuka Market Area:

$\begin{array}{ll}\text { Location Name } & \text { : Pramuka Market Area } \\ \text { Address } & : \text { Jl. Pramuka, Rt.12 / Rw.1, Palmeriam, kec. Matraman, East Jakarta } 13140 \\ \text { Year of Establishment } & : 1975 \\ \text { Head of Market Management } & : \text { Ajie Ruslan }\end{array}$

\subsection{Data Collection Methods}

The data collection method is a technique used by researchers to collect data. In this study, the data collection methods used were questionnaires/questionnaire, interviews, internet media, newspapers. 
1. Questionnaire: the researcher distributes questionnaires in the form of many questions to customers.

2. Interview: researchers conduct data collection in person with meetings with customers and ask questions to get information.

3. Prior Research Journal: researchers also make use of the Prior Research Journal to collect data.

The flowchart of the study in this study is as follows:

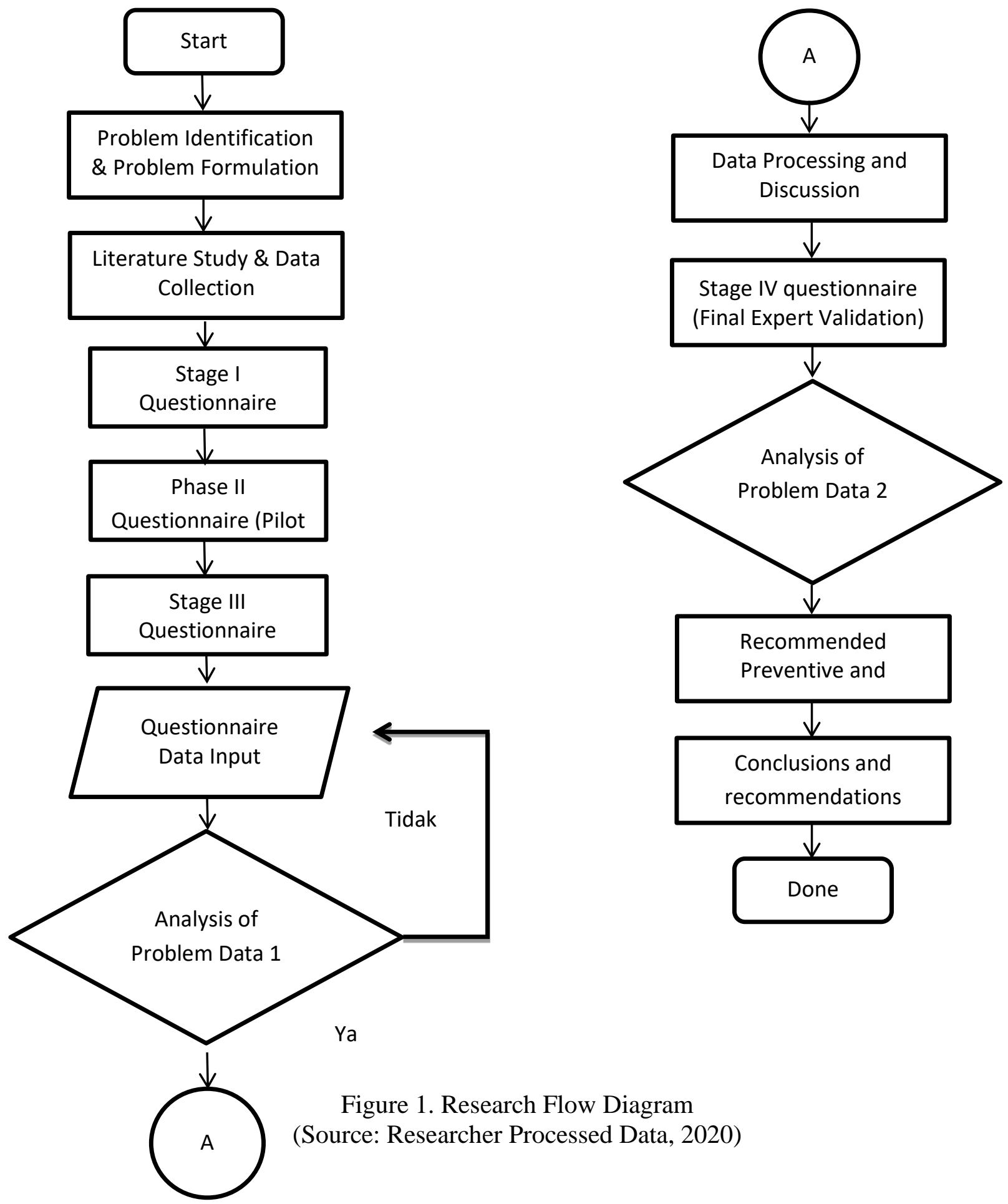




\subsection{Research Analysis Flow}

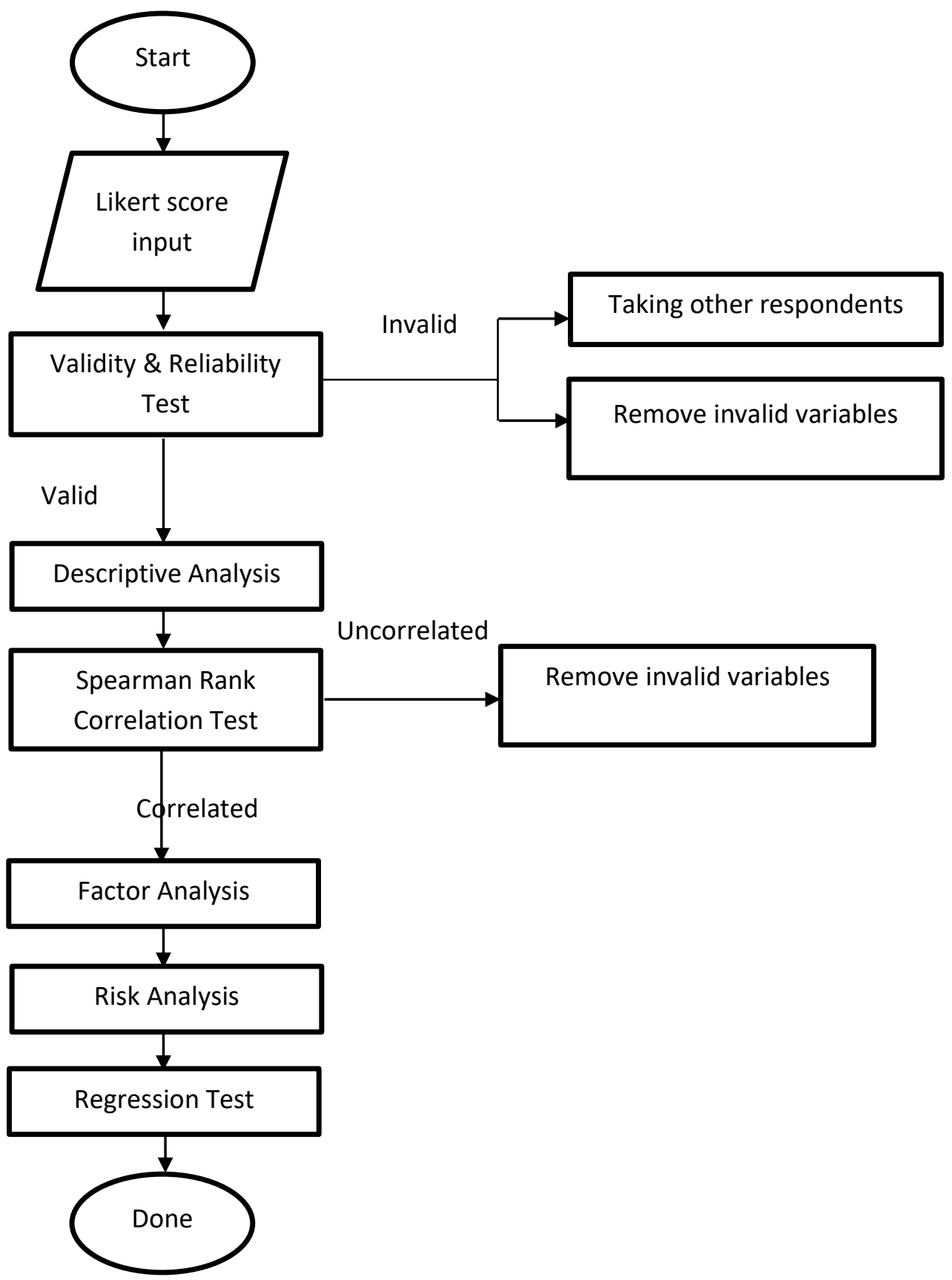

Figure 2. Research Analysis flowchart

(Source: Researcher Processed Data, 2020)

\section{Results and Discussion}

Data collection consisted of four stages which began with the distribution of questionnaires to 3 experts, followed by the distribution of pilot survey questionnaires, then the distribution of questionnaires to respondents and finally the validation of the final stage of experts to find out risk management. Of the 37 variables validated by experts, filtered to 33 variables to be analyzed. The filtered variables are X20, X30, X33, X36. 
VOLUME 2 | NUMBER 2 | MARCH 2020

Available online at http://proceedings.worldconference.id.

ISSN: 2656-1174 (online)

Table 1. Validity Test Results

\begin{tabular}{|c|c|c|c|c|c|c|}
\hline Variabel & $\begin{array}{c}\text { Scale } \\
\text { Mean if } \\
\text { Item } \\
\text { Deleted }\end{array}$ & $\begin{array}{c}\text { Scale } \\
\text { Variance if } \\
\text { Item } \\
\text { Deleted }\end{array}$ & $\begin{array}{l}\text { Corrected } \\
\text { Item-Total } \\
\text { Correlation }\end{array}$ & $\begin{array}{l}\text { Cronbach's } \\
\text { Alpha if } \\
\text { Item } \\
\text { Deleted }\end{array}$ & R Tabel & Kesimpulan \\
\hline $\mathrm{X} 1$ & 115,80 & 263,879 & 0,284 & 0,927 & 0,1966 & VALID \\
\hline $\mathrm{X} 2$ & 116,35 & 254,270 & 0,599 & 0,923 & 0,1966 & VALID \\
\hline X3 & 117,10 & 262,111 & 0,356 & 0,926 & 0,1966 & VALID \\
\hline $\mathrm{X} 4$ & 115,87 & 246,013 & 0,712 & 0,921 & 0,1966 & VALID \\
\hline $\mathrm{X} 5$ & 116,84 & 266,318 & 0,253 & 0,926 & 0,1966 & VALID \\
\hline X6 & 116,18 & 249,099 & 0,671 & 0,921 & 0,1966 & VALID \\
\hline X7 & 116,53 & 259,080 & 0,546 & 0,923 & 0,1966 & VALID \\
\hline $\mathrm{X} 8$ & 116,56 & 254,208 & 0,638 & 0,922 & 0,1966 & VALID \\
\hline X9 & 115,78 & 266,476 & 0,301 & 0,926 & 0,1966 & VALID \\
\hline X10 & 116,46 & 254,190 & 0,636 & 0,922 & 0,1966 & VALID \\
\hline X11 & 115,76 & 251,194 & 0,591 & 0,923 & 0,1966 & VALID \\
\hline X12 & 115,59 & 267,820 & 0,237 & 0,926 & 0,1966 & VALID \\
\hline X13 & 116,41 & 247,254 & 0,744 & 0,920 & 0,1966 & VALID \\
\hline X14 & 115,70 & 273,343 & 0,004 & 0,928 & 0,1966 & $\begin{array}{l}\text { TIDAK } \\
\text { VALID }\end{array}$ \\
\hline X15 & 116,50 & 248,556 & 0,722 & 0,921 & 0,1966 & VALID \\
\hline X16 & 115,48 & 259,404 & 0,522 & 0,924 & 0,1966 & VALID \\
\hline X17 & 115,68 & 264,684 & 0,326 & 0,926 & 0,1966 & VALID \\
\hline X18 & 116,93 & 254,611 & 0,613 & 0,922 & 0,1966 & VALID \\
\hline X19 & 116,03 & 250,938 & 0,692 & 0,921 & 0,1966 & VALID \\
\hline $\mathrm{X} 21$ & 115,44 & 263,138 & 0,393 & 0,925 & 0,1966 & VALID \\
\hline $\mathrm{X} 22$ & 116,15 & 261,705 & 0,430 & 0,925 & 0,1966 & VALID \\
\hline X23 & 115,48 & 266,091 & 0,281 & 0,926 & 0,1966 & VALID \\
\hline X24 & 116,65 & 250,614 & 0,682 & 0,921 & 0,1966 & VALID \\
\hline X25 & 117,15 & 253,725 & 0,635 & 0,922 & 0,1966 & VALID \\
\hline X26 & 115,81 & 265,772 & 0,372 & 0,925 & 0,1966 & VALID \\
\hline X27 & 115,56 & 262,047 & 0,413 & 0,925 & 0,1966 & VALID \\
\hline $\mathrm{X} 28$ & 117,22 & 252,598 & 0,646 & 0,922 & 0,1966 & VALID \\
\hline X29 & 115,96 & 261,594 & 0,458 & 0,924 & 0,1966 & VALID \\
\hline X31 & 116,32 & 247,876 & 0,676 & 0,921 & 0,1966 & VALID \\
\hline X32 & 115,67 & 252,668 & 0,658 & 0,922 & 0,1966 & VALID \\
\hline X34 & 115,70 & 263,586 & 0,389 & 0,925 & 0,1966 & VALID \\
\hline X35 & 115,66 & 265,419 & 0,254 & 0,927 & 0,1966 & VALID \\
\hline X37 & 116,32 & 257,856 & 0,491 & 0,924 & 0,1966 & VALID \\
\hline
\end{tabular}

(Source: Processed Data on Computer Software, 2020)

For reliability testing, the Cronbach's alpha method is used where the value must be greater than 0.6 for each variable and 0.8 for the entire variable to be considered reliable. Based on the reliability test results obtained show that all variable items in the study can be declared reliable and have a high level of reliability.

Table 2. Reliability Test Results

\begin{tabular}{cc}
\hline Cronbach's Alpha & N of Items \\
\hline 0,926 & 33 \\
\hline (Source: Processed Data on Computer Software, 2020)
\end{tabular}

\subsection{Correlation Test Results}

In testing the validity of the data by referring to the column correlation coefficient (rcount) compared to the rtable value. The rtable value for the 2-tailed test with a confidence level of $95 \%$ or a significance of $5 \%$ with the number of respondents 100 was 0.1966 for the Spearman correlation. For statistical decision making is a variable 


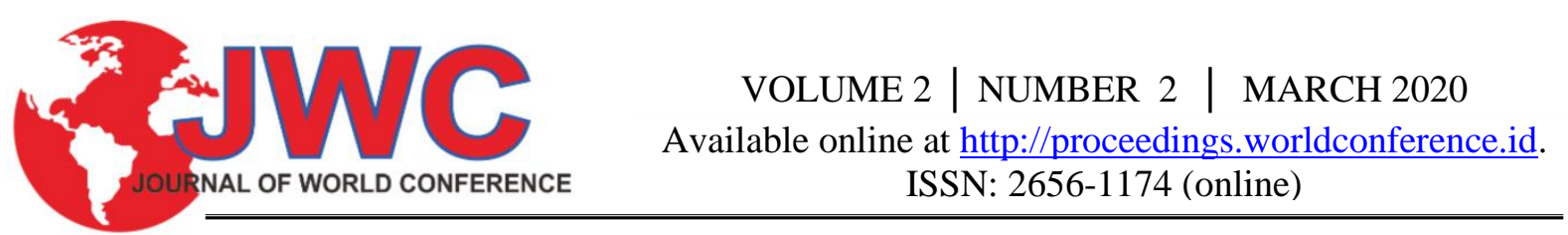

that has a correlation coefficient> 0.1966. The following table shows the output of the statistical data processing application, the results of the correlation test of variable X (risk factor) to the variable $\mathrm{Y}$ (customer satisfaction):

Table 3. Correlation Test

\begin{tabular}{|c|c|c|c|}
\hline Variabel & $\mathrm{N}$ & Correlation Coefficient & Sig. (2-tailed) \\
\hline $\mathrm{X} 1$ & 100 & 0,127 & 0,207 \\
\hline $\mathrm{X} 2$ & 100 & $334^{* *}$ & 0,001 \\
\hline $\mathrm{X} 3$ & 100 & $261^{* * *}$ & 0,009 \\
\hline $\mathrm{X} 4$ & 100 & $483^{* *}$ & 0,000 \\
\hline $\mathrm{X} 5$ & 100 & $208^{*}$ & 0,038 \\
\hline X6 & 100 &, $483^{* *}$ & 0,000 \\
\hline $\mathrm{X} 7$ & 100 & $451^{* *}$ & 0,000 \\
\hline $\mathrm{X} 8$ & 100 &, $441^{* *}$ & 0,000 \\
\hline X9 & 100 & 0,184 & 0,067 \\
\hline $\mathrm{X} 10$ & 100 &, $521^{* *}$ & 0,000 \\
\hline $\mathrm{X} 11$ & 100 & $405^{* *}$ & 0,000 \\
\hline $\mathrm{X} 12$ & 100 & $287^{* *}$ & 0,004 \\
\hline $\mathrm{X} 13$ & 100 &, $422^{* *}$ & 0,000 \\
\hline $\mathrm{X} 15$ & 100 & $-0,025$ & 0,808 \\
\hline X16 & 100 &, $412^{* *}$ & 0,000 \\
\hline $\mathrm{X} 17$ & 100 &, $362^{* *}$ & 0,000 \\
\hline $\mathrm{X} 18$ & 100 &, $202^{*}$ & 0,043 \\
\hline X19 & 100 &, $398^{* *}$ & 0,000 \\
\hline $\mathrm{X} 21$ & 100 & $446^{* * *}$ & 0,000 \\
\hline $\mathrm{X} 22$ & 100 &, $233^{*}$ & 0,020 \\
\hline X23 & 100 &, $309^{* *}$ & 0,002 \\
\hline X24 & 100 &, $261^{* *}$ & 0,009 \\
\hline X25 & 100 &, $441^{* * *}$ & 0,000 \\
\hline X26 & 100 & $602^{* *}$ & 0,000 \\
\hline X27 & 100 & 0,169 & 0,094 \\
\hline X28 & 100 &, $214^{*}$ & 0,033 \\
\hline X29 & 100 &, $598^{* *}$ & 0,000 \\
\hline X31 & 100 & $265^{* *}$ & 0,008 \\
\hline X32 & 100 &, $415^{* *}$ & 0,000 \\
\hline X34 & 100 &, $507^{* *}$ & 0,000 \\
\hline X35 & 100 &, $310^{* *}$ & 0,002 \\
\hline X37 & 100 & 0,188 & 0,061 \\
\hline
\end{tabular}

(Source: Processed Data on Computer Software, 2020)

Variables which are stated to have significant correlation levels are X2, X3, X4, X5, X6, X7, X10, X11, X12, X13, X16, X17, X18, X19, X21, X21, X23, X24, X25, X26, X28, X29, X31, X32, X33, X34, X35.

\subsection{Results of Regression Analysis}

The relationship model between the independent variables (Pramuka Market risk management) and the dependent variable (Increasing Customer Satisfaction) was studied by regression analysis using the Statistical Processing Program. The input for this regression analysis are 27 variables that have a significant correlation from the Spearman rank correlation test. Following are the outputs of the regression analysis:

Tabel 4. Model Summary

\begin{tabular}{ccccc}
\hline Model & $\mathrm{R}$ & R Square & Adjusted R Square & $\begin{array}{c}\text { Std. Error of the } \\
\text { Estimate }\end{array}$ \\
\hline 1 &, $569^{\mathrm{a}}$ & 0,323 & 0,317 & 0,477 \\
2 &, $664^{\mathrm{b}}$ & 0,441 & 0,429 & 0,436 \\
3 &, $701^{\mathrm{c}}$ & 0,491 & 0,475 & 0,418 \\
4 &, $718^{\mathrm{d}}$ & 0,515 & 0,495 & 0,410 \\
\hline
\end{tabular}

a. Predictors: (Constant), X29

b. Predictors: (Constant), X29, X7 


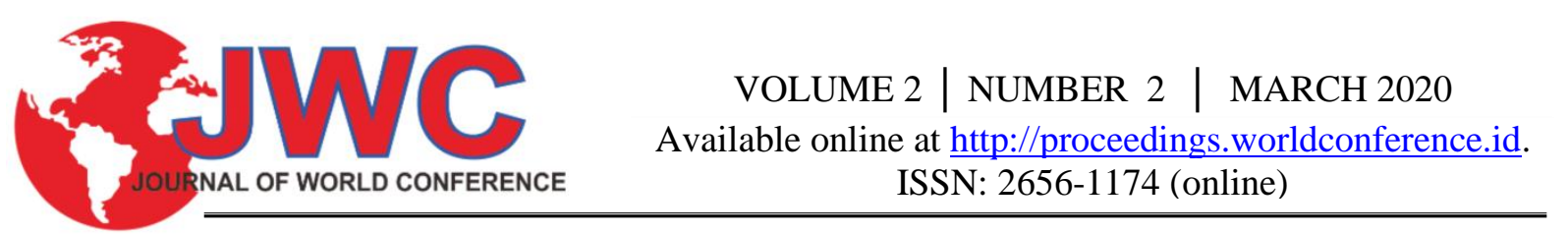

$\mathrm{X} 10=$ People break the rules

$\mathrm{X} 26=$ Condition of the roof of the building that has been worn out

So it can be translated as follows:

a. A constant of 1.874 states that if there is no value for each factor then the $\mathrm{Y}$ value is 1.874 .

b. X29 regression coefficient of 0.175 states that for each addition of 1 value of the variable X29, the value of $\mathrm{Y}$ increases by 0.175 . Then the level of customer satisfaction increases by $17.5 \%$ if the lighting system is improved.

c. The regression coefficient X7 of 0.196 states that for each addition of 1 value of the variable X7, the value of Y increases by 0.196 . Then the level of customer satisfaction increases by $19.6 \%$ if the parking management is improved.

d. X10 regression coefficient of 0.120 states that each addition of 1 value of the variable X10, then the value of Y increases by 0.120 . Then the level of customer satisfaction increases by $12 \%$ if there are no more people who break the rules.

e. X26 regression coefficient of 0.124 states that for each addition of 1 value of the variable X26, the value of $\mathrm{Y}$ increases by 0.124 . Then the level of customer satisfaction increases by $12.4 \%$ if the condition of the roof of the building that has been worn out immediately followed up

Hypothesis: from the results of the above output we can know the significance value of $0.000<0.005$, then $\mathrm{H} 0$ is rejected and $\mathrm{H} 1$ is accepted. HO Statement: If no management risk analysis is conducted on the scout market then it does not increase customer satisfaction, it is rejected. Whereas the H1 statement: If a management risk analysis is done in the scout market, it will increase customer satisfaction, which is accepted, which means there is a significant (significant) variable (X29, X7, X10, and X26) on the variable Y.

\subsection{Risk Rating Analysis}

The variables from the results of the data collection of respondents who have been reduced from the results of the validity and reliability tests are input from this stage of the analysis which is a number of 33 variables. Risk ranking analysis is performed on the results of the calculation of the average value of frequency and impact of risk.

Based on the matrix above, the range of values to determine risk are:

Low risk : $0.01-0.05$

Moderate risk $\quad: 0.06-0.25$

High risk $: 0.25-0.72$

Of the 100 questionnaires distributed to respondents, total impact and frequency data were obtained as follows:

The calculation of risk values and risk categories is shown in the following table 7. :

Table 7. Value and Risk Category

\begin{tabular}{ccccc}
\hline Variable & Impact $(\mathrm{D})$ & Frequency $(\mathrm{F})$ & Risk $(\mathrm{D}$ X F) & Risk Category \\
\hline X1 & 0,48 & 0,48 & 0,23 & Medium \\
X2 & 0,34 & 0,38 & 0,13 & Medium \\
X3 & 0,20 & 0,28 & 0,06 & Medium \\
X4 & 0,48 & 0,42 & 0,20 & Medium \\
X5 & 0,23 & 0,29 & 0,07 & Medium \\
X6 & 0,39 & 0,37 & 0,14 & Medium \\
X7 & 0,28 & 0,31 & 0,09 & Medium \\
X8 & 0,28 & 0,33 & 0,09 & Medium \\
X9 & 0,47 & 0,51 & 0,23 & Medium \\
X10 & 0,30 & 0,33 & 0,10 & Medium \\
X11 & 0,53 & 0,40 & 0,21 & Medium \\
X12 & 0,51 & 0,60 & 0,31 & Medium \\
X13 & 0,34 & 0,37 & 0,12 & High \\
X14 & 0,31 & 0,28 & 0,09 & High \\
X15 & 0,57 & 0,56 & 0,32 & Medium \\
X16 & 0,50 & 0,60 & 0,30 & Medium \\
X17 & 0,22 & 0,28 & 0,06 & 0,19 \\
X18 & 0,42 & 0,45 & &
\end{tabular}




\begin{tabular}{ccccc} 
VOLUME 2 | NUMBER 2 | MARCH 2020 \\
\hline Variable & Impact (D) & Frequency (F) & Risk (D X F) & Risk Category \\
\hline X19 & 0,58 & 0,20 & 0,12 & Medium \\
X21 & 0,36 & 0,23 & 0,08 & Medium \\
X22 & 0,57 & 0,40 & 0,23 & Medium \\
X23 & 0,27 & 0,31 & 0,08 & Medium \\
X24 & 0,18 & 0,26 & 0,05 & Medium \\
X25 & 0,44 & 0,41 & 0,18 & Medium \\
X26 & 0,53 & 0,50 & 0,26 & High \\
X27 & 0,18 & 0,23 & 0,04 & Medium \\
X28 & 0,41 & 0,54 & 0,22 & Medium \\
X29 & 0,36 & 0,33 & 0,12 & Medium \\
X31 & 0,53 & 0,42 & 0,22 & High \\
X32 & 0,50 & 0,52 & 0,26 & Medium \\
X34 & 0,33 & 0,23 & 0,07 & Medium \\
X35 & 0,33 & 0,39 & 0,13 & Medium \\
X37 & 0,30 & 0,50 & 0,15 & ondine \\
\hline
\end{tabular}

Variables that have a high risk category are as follows:

Table 10. High Risk Categories

\begin{tabular}{cl}
\hline Variable & \multicolumn{1}{c}{ Description } \\
\hline X12 & Special public transportation stops are covered by On-Street parking \\
X15 & Bad odor \\
X16 & Humid and dark conditions in the bird market \\
X26 & The condition of the roof of the building that has been worn out \\
X32 & There is no loading and unloading area \\
\hline
\end{tabular}

(Source: Researcher Processed Data, 2020)

\section{Conclusions and Recommendations \\ 5.1 Conclusions}

Based on the results of the regression analysis presented and the results obtained, it can be concluded that there are 4 dominant factors that influence customer satisfaction. The following dominant variables and handling / strategy for each variable:

1. The dominant factor in management risk in the Jakarta scout market area which has an influence on customer satisfaction, namely, X29: Poor lighting system (17.5\%), X7: Poor parking management between intermingled markets (19.6\%), X10 : People break the rules (12\%), X26: Condition of the roof of the building that has been worn $(12.4 \%)$.

2. Handling / Strategy on variables that influence the following:

$\mathrm{X} 29$ : The lighting system is not good

a. Cause: The lack of management of the lighting system in the vicinity.

b. Impact: Disrupts transactions between customers and buyers.

c. Preventive Measures: Check the lighting system at every angle once or twice a month

d. Corrective Action: Add lighting or change the lighting system using LED lights in every corner that looks less light

X7: Poor parking management between markets intermingles
a. Cause: Lack of parking space provided by the inter-market manager.
b. Impact: Stacking of vehicles in a parking area that can disrupt customer comfort
c. Preventive Measures: Utilizing vacant land to be used as an inter-market parking area
d. Corrective Action: - Provide parking attendants in each respective area
- Reinforce parking users who park their vehicles not in their place.

X10: People break the rules

a. Cause: Lack of personal awareness of each of the applicable rules.

b. Impact: Causing inconvenience for other people in the surrounding community.

c. Preventive Measures: - Instill awareness in yourself not to break the rules

- Provides several signs needed to be a reminder 


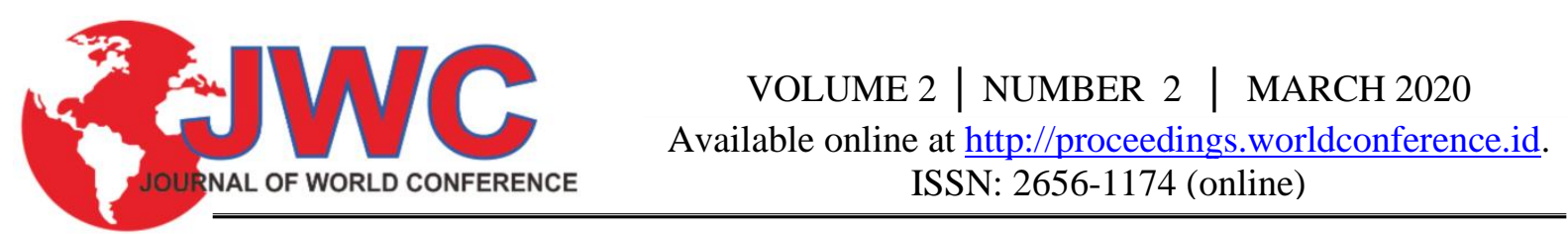

d. Corrective Action: Strict rebuke for rule breakers

X26: Condition of the roof of the building that has been worn out

a. Cause: Lack of management attention related to the state of the building roof/market building.

b. Impact: Can cause the roof to collapse and can endanger the safety of all people on the market.

c. Preventive Measures: Conduct routine checks two or three times a month on the condition of the roof of the building

d. Corrective Action: Roofs that have cracked or worn out are followed up immediately

Based on the results of the risk rating analysis presented and the results obtained, it can be concluded that 5 variables have a high level of risk that can affect customer satisfaction. The following variables with high risk and handling/strategies for each variable:

The dominant factor in managing risk in the Jakarta scout market area that influences customer satisfaction is, X12: Special places for public transport stops covered with On-Sreet parking, X15: Bad odor, X16: Humid and dark conditions in the bird market, X26: Outdated building roof condition, X32: No loading and unloading areas

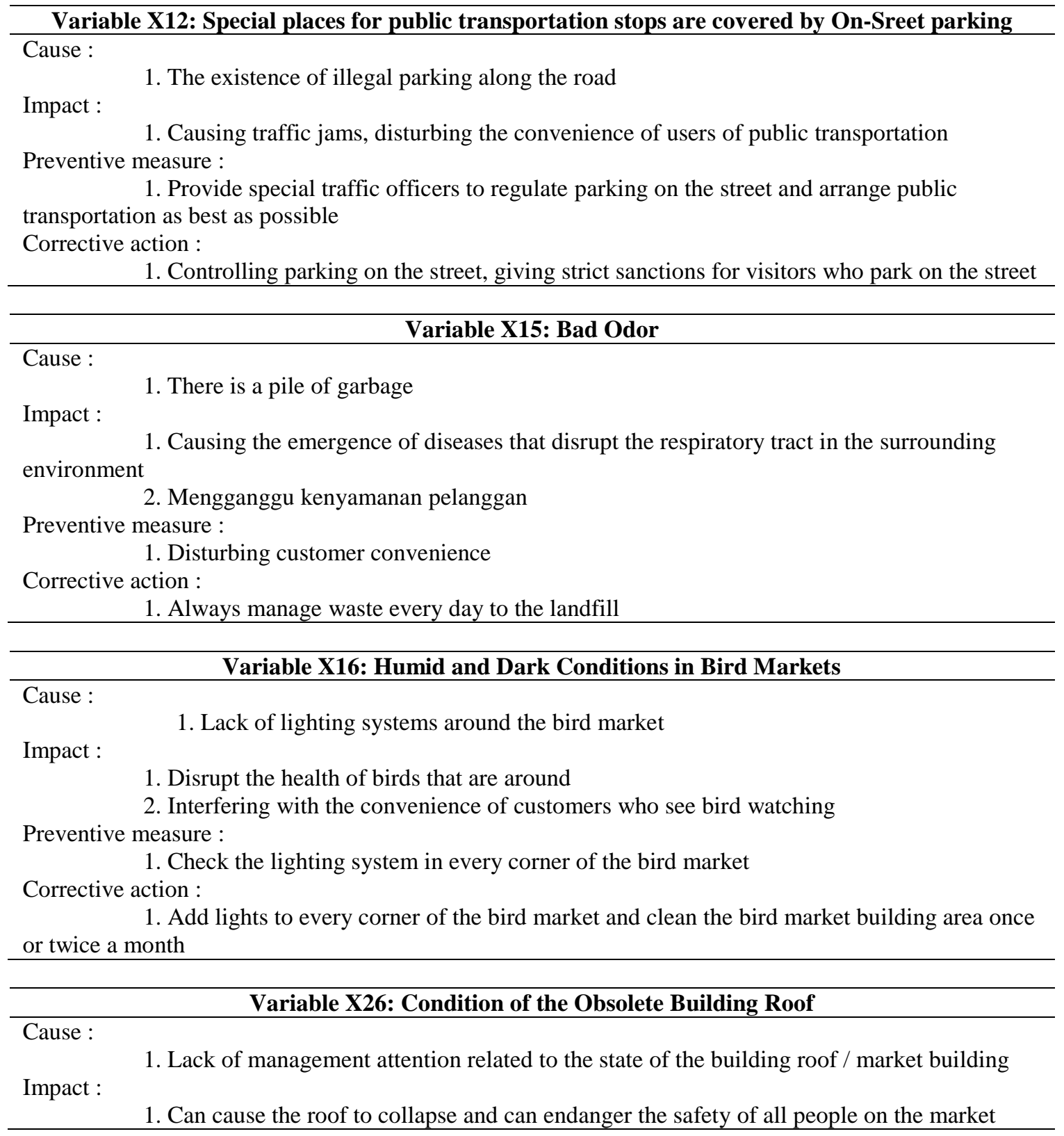




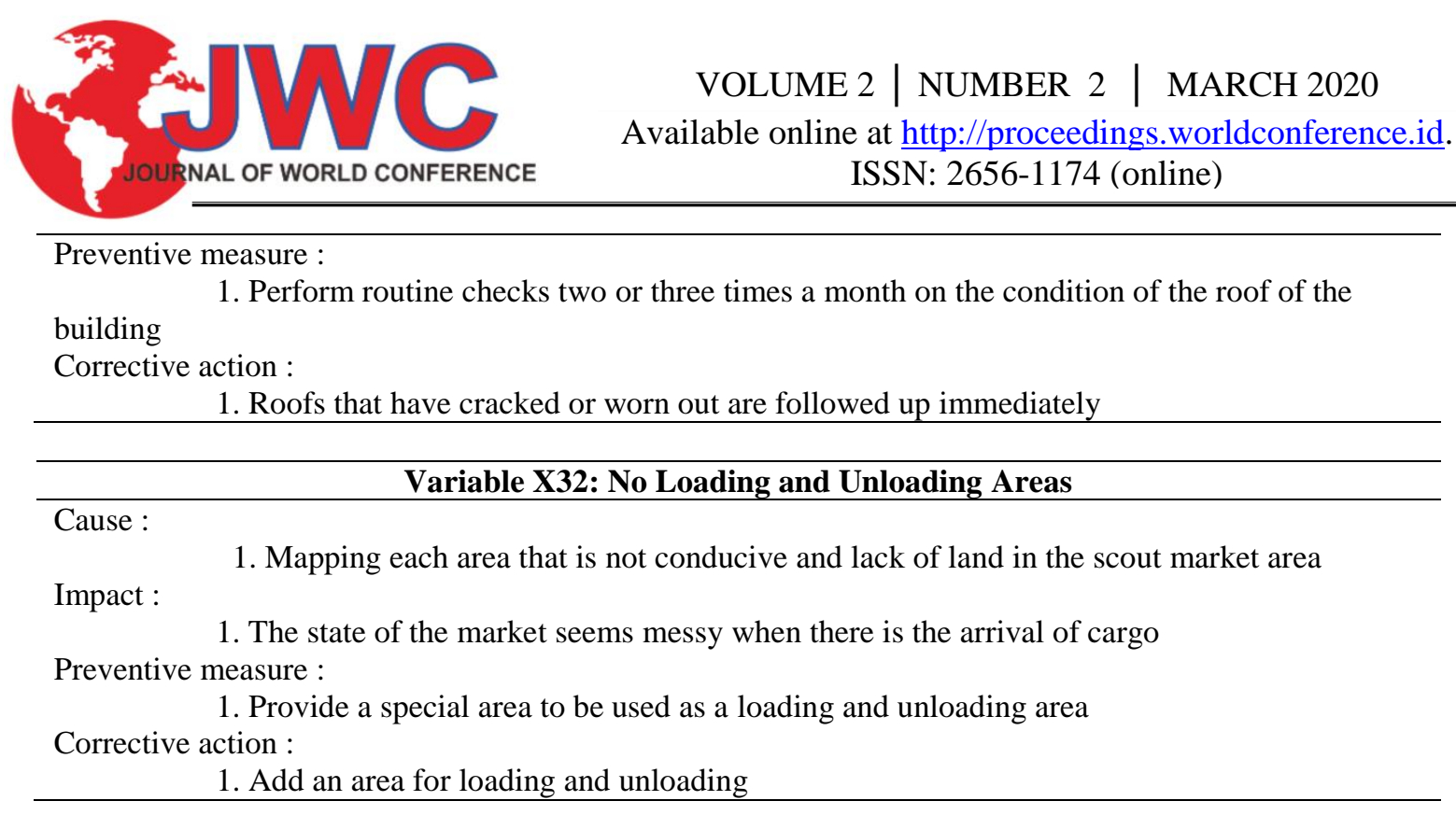

\subsection{Recommendations}

1. This research specifically reviews the risks to the management of Jakarta's scout market area infrastructure to improve customer satisfaction. Based on the results obtained, there are several factors that influence the customer satisfaction of the scout market, therefore it is prepared to immediately make improvements and improvements to the infrastructure to increase customer satisfaction in the scout market.

2. This research specifically reviews the risks in the management of the scout market area which is seen from the perspective of increasing customer satisfaction, so that it can then be examined from the perspective of the efforts made by the market management.

\section{References}

[1] Anik Lestari Andjarwati, Sri Setyo Aryani, Sanaji (2018). Analisis pemetaan risiko pengelolaan pasar sebagai dasar perencanaan model pengelolaan dan pengendalian risiko pasar rakyat di kabupaten Siduarjo.

[2] Ida Bagus Ngurah Pubawijaya. (2017) Analisis risiko pada proyek pembangunan sentral parkir di pasar Badung

[3] Maesaroh, Rahayu, Bekti. Santoso, R Slamet. 2015. Analisis Strategi Pengelolaan Pasar Johar Oleh Dinas Pasar Kota Semarang. Universitas Diponegoro.

[4] Minarni, Eny., Nurhadi, Ahmad., ( 2017 ) : Analisis tingkat kepuasan pelanggan terhadap pelayanan pasar tradisional besuki. Tulung Agung

[5] Nurrohman., Minarsih, Maria M., Warso, Moh Mukeri, ( 2016 ) : Analisis pengaruh letak, variasi produk dan lingkungan fisik terhadap loyalitas konsumen ( studi kasus PD pasar gayamsari semarang ). Semarang

[6] Peraturan Menteri Pekerjaan Umum No. 30 Tahun 2006 tentang Pedoman Teknis Fasilitas dan Aksesibilitas pada Bangunan Gedung

[7] Peraturan Menteri Perdagangan Republik Indonesia No. 27 Tahun 2015 tentang Rencana Strategis Kementerian Perdagangan Tahun 2015-2019.

[8] Peraturan Menteri Perdagangan Republik Indonesia No. 48 Tahun 2013 tentang Pedoman Pembangunan dan Pengelolaan Sarana Distribusi Perdagangan.

[9] Project Management Institute. 2018. A Guide to the Project Management Body of Knowledge (PMBOK® Guide) - Sixth Edition. Pennsylvania USA : Project Management Institute, Inc

[10] Sugiyono. (2017). Metode Penelitian Kuantitatif, Kualitatif, dan R\&D. Bandung : Alfabeta,CV. 


\section{Biographies}

Muhammad Agfi Alfian is a final year student at mercubuana university who is researching his final project. He has worked in construction management in the Jakarta area, he handles housing projects such as housing projects in the area of Jl.Permata Hijau and Gunawarman. he also worked on building interiors in the 8th district of Jakarta.

Ali Sunandar is a researcher at the Center for Sustainable Infrastructure Development UI (CSID UI) and a lecturer at Mercubuana University. Ali is also active in various organizations such as the Indonesian Transportation Society (MTI), the Indonesian Infrastructure Society (MII) and the Indonesia Economic Forum (IEF). His main interest is the development of sustainable economic and social infrastructure in Jakarta, especially in improving institutional approaches and funding innovations. With the institutional harmonization approach to infrastructure bureaucracy and funding innovation, Jakarta not only has the infrastructure but is also service-oriented to citizens. 